\title{
Effect of different beta-glucan preparation pretreatments on fortified bread quality
}

\author{
Marcin Andrzej KUREK ${ }^{1 *}$, Jarosław WYRWISZ ${ }^{1}$, Magdalena BRZESKA ${ }^{1}$, Małgorzata MOCZKOWSKA ${ }^{1}$, \\ Sabina KARP ${ }^{1}$, Agnieszka WIERZBICKA ${ }^{1}$
}

\begin{abstract}
This research explores the different beta-glucan preparation pretreatments prior to fortifying the bread (hydrating, freezing, boiling, blendering and their combination). Breads containing hydrated or dry beta-glucan preparations demonstrated lower values of specific volume than the control. On the other hand, the beta-glucan preparation, which was boiled or blendered after freezing showed higher specific volume. The firmest bread was achieved by adding beta-glucan preparation which was hydrated and blendered (significant at $\mathrm{p} \leq 0.05$ ) and the least firm was after application of a frozen blendered preparation. In our study, we researched the influence of pretreatment the beta-glucan preparation on the concentration of this compound. Our breads contain from 1.62 to $1.99 \mathrm{~g}$ beta-glucan/100 g of product. It seems that the best way of pretreatment is drying, freezing or boiling after freezing the beta-glucan preparation (significant at $\mathrm{p} \leq 0.05$ ). In general, the best performing method was boiling the beta-glucan preparation following dough addition.
\end{abstract}

Keywords: beta-glucan; pretreatment; bread; quality.

Practical Application: Research helps to provide most appropriate beta-glucan preparation prior to baking.

\section{Introduction}

The increased awareness of consumers regarding health issues has evoked food producers to address the need to supply the market with functional products. Bakery products are one of the most widely eaten products all over the world. During the last decade, these products have been explored for development of their functionality for human health (Mudgil et al., 2016).

One of the substances that could enhance bakery products in their functionality is beta-glucan. This is a polysaccharide that can be found in cereals, like oats and barley (Wang et al., 2016). Beta-glucan's health benefits were proved by the European Food Safety Authority (2011) with claims that beta-glucan is recognized as an agent that could lower the blood cholesterol and postprandial glucose response. Moreover, the lowering of LDL cholesterol levels was documented as well

Generally, the fortification of bakery products with dietary fiber could lower its quality. Although beta-glucan is a valuable nutrient, its application in bakery products is difficult due to its viscosity and water-holding capacity (Harasym et al., 2015). There are some techniques of pretreatment of beta-glucan preparations or other cereal raw materials following bread making and their consist of high-pressure homogenization, by adding antioxidants, enzymatic hydrolysis or thermo-mechanical degradation (Harasym et al., 2015; Taghinia et al., 2016; Tosh et al., 2010). Some of them are effective but they have drawbacks like high cost, low yield and long processing times which makes them inapplicable for the industry (Sibakov et al., 2011).
Some of the mechanical treatments of polysaccharide raw material was explored previously and thermal treatment like freezing or freeze milling were also applied to spelt grains or beta-glucans from barleys (Benito-Román et al., 2013; Niemi et al., 2012). However, there is no a comprehensive approach towards using different pretreatments of beta-glucan preparations on the quality of fortified wheat bread. Therefore, we decided to present in this research the application of freezing, blendering, boiling and mixing these treatments with each other in the pretreatment of the beta-glucan preparation prior to fortifying wheat bread.

\section{Materials and methods}

\subsection{Raw materials}

Commercial wheat flour was provided by a local supplier and consisted of $13.70 \%$ moisture content, $10.86 \%$ proteins, $0.49 \%$ ash and $27.4 \%$ gluten. The basic component levels in flour were measured with near-infrared spectroscopy (NIRFlex N-500, Buchi, Switzerland). The oat beta-glucan preparation consisted of $44 \%$ dietary fibre ( $23 \%$ of insoluble fractions, $21 \%$ of soluble fractions-containing 16\% beta-glucan) (Microstructure Inc., Poland). Other constituents of dough like salt and fresh yeast water were bought in a local supermarket.

\subsection{Beta-glucan preparation pretreatment}

The beta-glucan preparations were done as presented on the scheme (Figure 1). The control sample was the bread without any beta-glucan preparation addition. Dry sample was the 


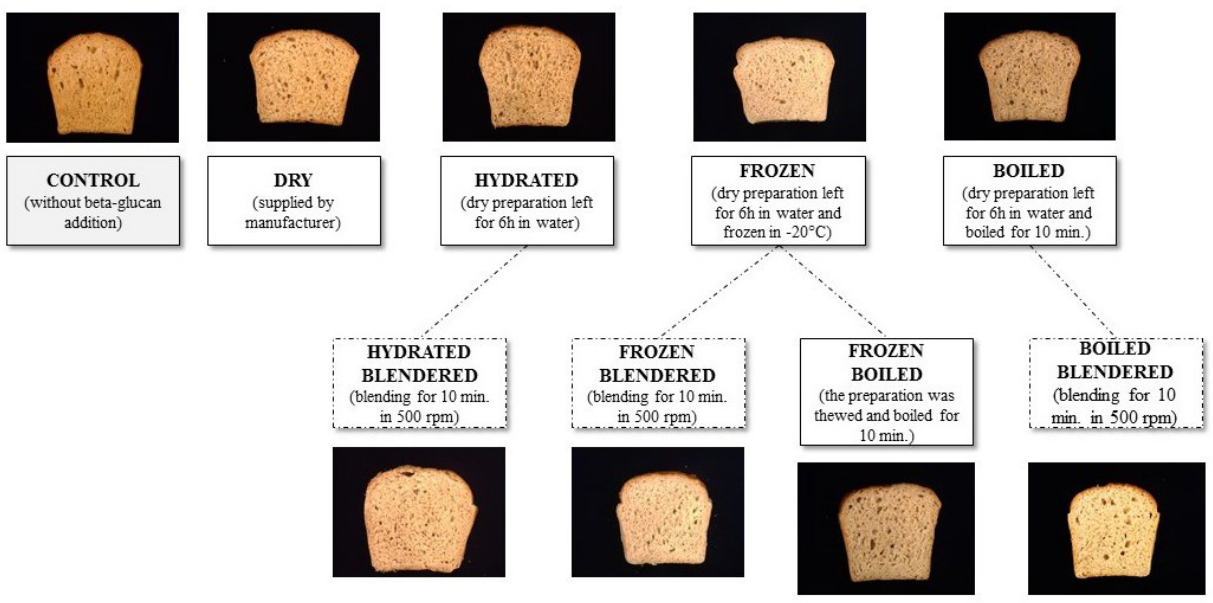

Figure 1. The pretreatment of beta-glucan preparation presented as experiment design.

beta-glucan preparation with a moisture content $12 \%$ in the form of bright yellow powder. The hydrated sample was examined to find out whether hydration of beta-glucan and colloid forming could influence the consistency of dough and final bread quality. Boiling of the beta-glucan preparation was done to eliminate the interference of starch gelatinization from the preparation during baking and was done prior to mixing. Freezing was conducted to find out whether gentle sublimation of water while thawing from the hydrated preparation influences the quality of bread. The blendered samples were done to decrease the particle size of beta-glucan. The ratio between water and beta-glucan dry preparation in all samples was 6:1 (v/w).

\subsection{Bread preparation}

The bread was prepared as in a previous study (Kurek et al., 2015). Briefly, to generate the dough (500 $\mathrm{g}$ of flour, $9 \mathrm{~g}$ of vital gluten, and $8 \mathrm{~g}$ of salt and $8 \mathrm{~g}$ of salt), $12 \mathrm{~g}$ of the fiber preparation was used per $100 \mathrm{~g}$ of the flour mixture to achieve a final amount of $2 \mathrm{~g}$ of beta-glucan per $100 \mathrm{~g}$. The ingredients were mixed for $6 \mathrm{~min}$ at $200 \mathrm{rpm}$ in a TRQ-42, RM Spiral mixer (Gastro, Poland). Water was added based on rheological measurements to achieve $500 \mathrm{BU}$ (Brabender Units). Preliminary fermentation was conducted at $37^{\circ} \mathrm{C}$ and $80 \%$ relative humidity for $60 \mathrm{~min}$. The mixer bowl was turned once after $30 \mathrm{~min}$, and the dough was divided into $350 \mathrm{~g}$ pieces. Each piece was inserted into forms for the proofing process until reaching oven maturity $\left(37^{\circ} \mathrm{C}\right.$, $80 \%$ relative humidity). The direct, single-phase method was used to bake the bread. Baking was conducted at $220^{\circ} \mathrm{C}$ for 25 minutes in a convection oven (Convection oven CPE 110, Kuppersbuch, Germany). There was a batch of 6 loaves baked from each beta-glucan preparation.

\subsection{Rheology}

Rheological measurements were conducted with a Mars III rheometer (Thermo Haake). The frequency sweep test was conducted in the plate-cone geometry $(60 \mathrm{~mm})$ with a 2-mm gap. The frequency of oscillation to compare the samples was $1 \mathrm{~Hz}$, shear stress was $60 \mathrm{~Pa}$, angle rotation sensor was at $2^{\circ}$, and temperature of the measurement was $25^{\circ} \mathrm{C}$. Measurements were performed in triplicate and the elastic modulus $G^{\prime}$ was the measured parameter.

\subsection{Specific volume}

The volume of baked bread rolls during storage was determined according to the rapeseed displacement method (López, 2014). The results are the average of four replicates and presented as volume in $\mathrm{mL} / \mathrm{g}$ of product.

\subsection{Bread texture}

Mechanical characteristics of bread in a double compression cycle were recorded in the Instron 5965 Universal Testing Machine (Instron, USA) with a maximal load of $500 \mathrm{~N}, 50 \%$ penetration depth with a $40 \mathrm{~mm}$ diameter probe and a $20 \mathrm{~s}$ gap between cycles on $20 \times 20 \times 20 \mathrm{~mm}$ crumb cubes. The results were expressed as selected parameters of TPA, the maximum level of firmness, springiness and cohesiveness. The parameters analyzed were firmness (the peak force during first compression; $\mathrm{N}$ ), springiness (the ratio between the recovered height after the first compression and the original sample height), and cohesiveness (area 2/area 1; -). Measurements were taken $24 \mathrm{~h}$ after baking. The texture studies were conducted in triplicate for each sample.

\subsection{Porosity}

Computer image analysis of TIFF images were used to estimate porosity, as previously described (Kurek et al., 2016). The loaf was cut into 2.5 -cm-thick slices. The slices were digitally photographed using lightening from lamps, with the color temperature at $5400 \mathrm{~K}$. The measurement of porosity involved archiving the images of the sample by a digital camera (Micro Publisher 5.0 RTV, QImaging, BC, Canada) equipped with a linear polarizing filter of $46 \mathrm{~mm}$ (Keiser, CA, USA), and a lighting system (RB-5004-HF, Kaiser, CA, USA) with 4 fluorescent lamps (Dulux L 36W/954, AC 230V/50Hz, Osram GmbH, Munich, Germany) and a color temperature of $5400 \mathrm{~K}$. Pictures were 
taken at a resolution of $2560 \times 1920$ pixels. The digital camera was connected to a PC computer using the Image Pro Plus 7.0 software (Media Cybernetics Inc., MD, USA). The software was used to calculate: the pore size using the calibration ruler, presented in $\mathrm{mm}^{2}$; the porosity, the area covered by pores on the whole area of the examined slice (in \%).

\subsection{Crumb color}

Color determinations were carried out on bread crumbs $24 \mathrm{~h}$ after baking using the Minolta CR- 400 colorimeter (Konica Minolta Inc., Japan) with illuminant D65, and a measurement area of $\varnothing=8 \mathrm{~mm}$, standard observers $2^{\circ}$. Three different slices were analyzed for color 10 times and the results were expressed in accordance to the CIELab color space. Determined parameters were $\mathrm{L}(\mathrm{L}=0$ (black) and $\mathrm{L}=100$ (white)), $\mathrm{a}(-\mathrm{a}=$ greenness and $+\mathrm{a}=$ redness), $\mathrm{b}(-\mathrm{b}=$ blueness and $+\mathrm{b}=$ yellowness). Then, the difference of color, $\Delta \mathrm{E}$, was calculated taking the control sample as the reference material with the following Equation 1:

$$
\Delta E=\sqrt{\left(L_{0}-L_{1}\right)^{2}+\left(a_{0}-a_{1}\right)^{2}+\left(b_{0}-b_{1}\right)^{2}}
$$

\subsection{Water content}

The water activity was measured by the dew point methodology using a Water Activity Meter 4TE (Aqualab, Pullman, USA).

\subsection{Beta-glucan}

The beta-glucan content in bread was determined by employing the AOAC method (Method 995.16), with modifications (beta-glucan Assay Kit - Mixed Linkage, Megazyme, Ireland) (Association of Official Analytical Chemists, 2010).

\subsection{Statistics}

The two sample comparison procedure and the ANOVA were performed to determine whether or not there were significant differences in the comparison of two or more than two samples. This was achieved using Statistica 10 (StatSoft, Tulsa, USA), considering $p$-values of less than 0.05 if operating at the $5 \%$ significance level. The correlations were estimated using the Pearson's test to assess whether the beta-glucan content is connected with other measured parameters.

\section{Results and discussion}

\subsection{Rheology}

The rheological measurements were conducted on the beta-glucan preparations. Significant differences were observed between the samples. In general, the G' showed the tendency to be lower parallel to the heaviness of treatments (Figure 2). The highest G' values were recorded in the sample of hydrated $(1222 \mathrm{~Pa})$, meaning the preparation that was allowed to hydrate without any force or thermal treatment had the stiffest consistency. In all samples, the blendered preparations had lower values than the non-blendered. This could be caused by the different water migration in the beta-glucan when the particle size is lower (Liu et al., 2015).

\subsection{Volume measurement}

Specific volume is a significant parameter when studying the quality of bread and involves the volume and weight of bread. Figure 3 depicts the changes in the specific volume of bread crumb prepared with a beta-glucan preparation after different pretreatments. The results showed that pretreatment of the beta-glucan preparation influenced specific volume. Breads containing hydrated or dry beta-glucan preparations demonstrated lower values of specific volume than control (significant at $\mathrm{p} \leq 0.05$ ). On the other hand, beta-glucan preparations that were boiled or blendered after freezing showed higher levels.

Only bread prepared from the beta-glucan preparation after freezing has a similar specific volume to control. Significant differences between the mean values in control and analyzed breads ( $\mathrm{p} \leq 0.05$ ) occurred for products containing blendered or boiled beta-glucan preparations (after boiled, frozen or hydrated). Generally, beta-glucan addition caused a lowering of the specific volume of bread, which is reported by other authors (Mudgil et al., 2016). In our study, the increase of bread loaf volume could be caused by blendering the samples because this decreases the particles of beta-glucan preparations. Moreover, the boiled sample had the highest specific volume due to the prior gelatinization of starch (Aghamirzaei et al., 2015). The

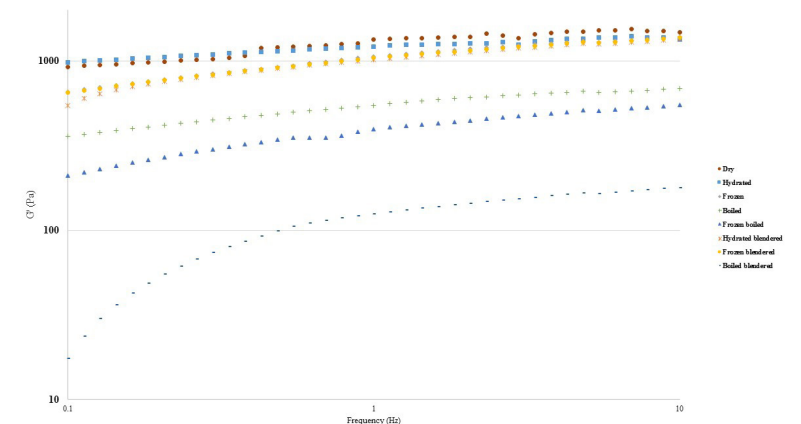

Figure 2. Influence of different pretreatment of $\beta$-glucan preparation on the elastic modulus - G' in the frequency sweep test.

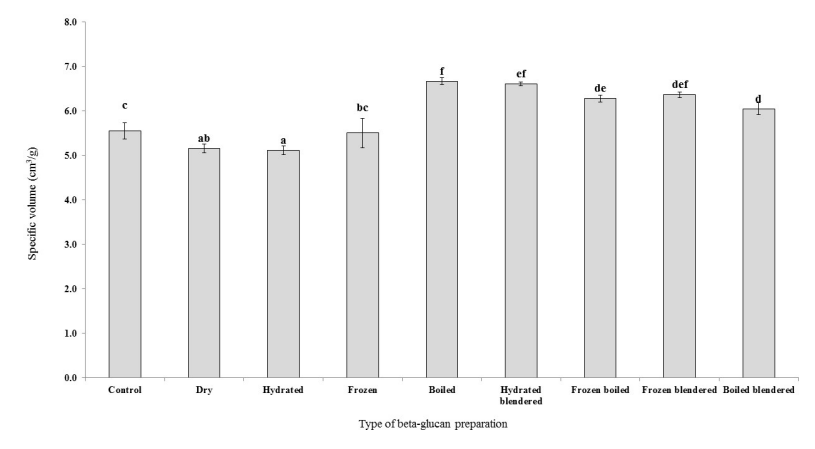

Figure 3. Influence of different pretreatment of $\beta$-glucan preparation on the specific volume of bread crumb prepared from those preparation. Letters $a, b, c$ indicate the significant differences between the mean values in columns $(\mathrm{p} \leq 0.05)$. 
heat treatment is responsible for changing the viscosity of beta-glucan which is caused by decreasing the molecular weight of beta-glucan (Ames et al., 2015).

\subsection{Texture profile analysis and porosity}

The effects of different beta-glucan preparation pretreatments on bread firmness, springiness, cohesiveness and porosity is shown in Table 1 . The firmest bread was achieved by adding a beta-glucan preparation which was hydrated and blendered (significant at $\mathrm{p} \leq 0.05$ ) and the least firm was after application of the frozen blendered preparation (significant at $\mathrm{p} \leq 0.05$ ).

The hydrated and blendered beta-glucan sample could lead to higher absorption of water due to decreasing particle size and a higher surface development. Excess water that is absorbed during mixing is prone to evaporate during baking, so the structure losses its softness (Kurek et al., 2017). All breads containing the beta-glucan preparation had higher springiness than the control, but only the addition of dry or hydrated blendered beta-glucan preparations showed significant differences $(\mathrm{p} \leq 0.05)$. The preparation of beta-glucan prior to mixing of dough could hold more water than the constituents of the flour so the springiness is higher (Martínez et al., 2014). Bread's cohesiveness was demonstrated between 0.57 and 0.67 , but there were no significant differences between all groups. Different pretreatments of the beta-glucan preparation influenced the porosity and mean pore size which could be caused by the depolymerization of the constituents of bread (starch-gluten network) which leads to a different formation of the bread's structure. Beta-glucan is a hydrocolloid which could interfere during baking due to gelatinization at nearly the same temperature as starch (Symons \& Brennan, 2004). However, the techno-functional properties of bread could be preserved after adding beta-glucan (Collar \& Angioloni, 2014).

\subsection{Color changes}

For all pretreated beta-glucan preparations, $\Delta \mathrm{E}$ is over 3.5 (Table 1) and even an untrained observer can notice the difference between the color of the bread prepared with and without a beta-glucan preparation (Robertson, 1990). The most noticeable difference is in case of the preparation which was boiled
$(\Delta \mathrm{E}=6.12)$. In general, the lightness $\left(\mathrm{L}^{*}\right)$ of bread prepared with beta-glucan is lower than the control sample. This could be caused by the addition of beta-glucan $\left(L^{*}=62.15, a^{*}=0.12\right.$ and $\left.b^{*}=13.18\right)$ and the new bindings of beta-glucan, as the polysaccharide and proteins which are the normal constituent of dough will lead to the carmelization and increased concentration of Maillard reactions products (Erbas et al., 2012).

\subsection{Water activity}

The next parameter measured was water activity (Figure 4.). The higher value of $\mathrm{a}_{\mathrm{w}}$ in food, the easier microorganisms growth occurs (Altamirano-Fortoul \& Rosell, 2011). Bacteria usually require at least $\mathrm{a}_{\mathrm{w}}=0.91$, which all breads had in our study. The lowest value of water activity after baking occurred with beta-glucan in the dry preparation or after freezing and blendering. Freezing or boiling preparations provided the highest $\mathrm{a}_{\mathrm{w}}$ in bread crumb (significant at $\mathrm{p} \leq 0.05$ ). Similar water activity to control was observed in the bread with hydrated and hydrated blendered preparation. The increase of water addition to obtain the optimal rheological properties of dough could lead to the impression that water is more accessible for bacteria and molds (Kariluoto et al., 2014).

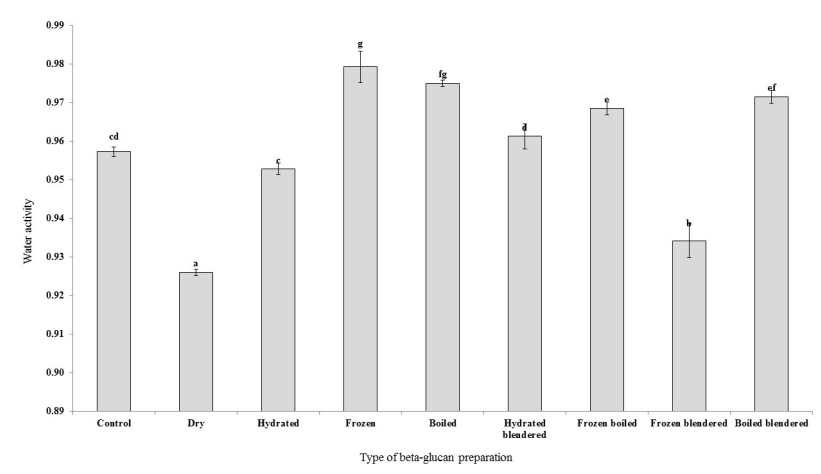

Figure 4. The water activity of bread crumb prepared with $\beta$-glucan preparation after different pretreatment. Letters $a, b, c$ indicate the significant differences between the mean values in columns $(\mathrm{p} \leq 0.05)$.

Table 1. The texture profile analysis (TPA), porosity and color parameters of bread crumb prepared with beta-glucan preparation after different pretreatment.

\begin{tabular}{|c|c|c|c|c|c|c|c|c|c|}
\hline Pretreatment & $\begin{array}{c}\text { Firmness } \\
(\mathrm{N})\end{array}$ & Springness & Cohesiveness & Porosity (\%) & $\begin{array}{l}\text { Pore mean } \\
\text { size }\left(\mathbf{m m}^{2}\right)\end{array}$ & $\mathbf{L}^{*}$ & $a^{*}$ & $\mathbf{b}^{*}$ & $\Delta \mathrm{E}$ \\
\hline Control & $2.80 \pm 0.37^{\mathrm{ab}}$ & $0.59 \pm 0.03^{\mathrm{a}}$ & $0.57 \pm 0.04$ & $0.35 \pm 0.01^{\mathrm{cd}}$ & $0.44 \pm 0.01^{\mathrm{ab}}$ & $70.75 \pm 1.85$ & $-0.93 \pm 0.04^{\mathrm{b}}$ & $11.06 \pm 0.55^{\mathrm{b}}$ & - \\
\hline Dry & $3.74 \pm 1.11^{\mathrm{ab}}$ & $0.79 \pm 0.04^{\mathrm{b}}$ & $0.66 \pm 0.05$ & $0.38 \pm 0.01^{\mathrm{de}}$ & $0.43 \pm 0.01^{\mathrm{a}}$ & $67.23 \pm 2.03$ & $-0.19 \pm 0.23^{\mathrm{a}}$ & $14.26 \pm 0.78^{\mathrm{a}}$ & 4.81 \\
\hline Frozen & $4.15 \pm 0.60^{\mathrm{ab}}$ & $0.66 \pm 0.09^{\mathrm{ab}}$ & $0.67 \pm 0.08$ & $0.41 \pm 0.05^{\mathrm{ef}}$ & $0.55 \pm 0.05^{\mathrm{cd}}$ & $67.66 \pm 1.76$ & $-0.21 \pm 0.46^{\mathrm{a}}$ & $15.66 \pm 1.57^{\mathrm{a}}$ & 5.59 \\
\hline Boiled & $3.14 \pm 1.05^{\mathrm{ab}}$ & $0.71 \pm 0.09^{\mathrm{ab}}$ & $0.57 \pm 0.05$ & $0.45 \pm 0.01^{\mathrm{f}}$ & $0.56 \pm 0.01^{\mathrm{d}}$ & $65.48 \pm 3.92$ & $-0.17 \pm 0.10^{\mathrm{a}}$ & $14.09 \pm 1.09^{\mathrm{a}}$ & 6.12 \\
\hline Frozen boiled & $3.41 \pm 0.92^{\mathrm{ab}}$ & $0.71 \pm 0.05^{\mathrm{ab}}$ & $0.64 \pm 0.02$ & $0.24 \pm 0.01^{\mathrm{ab}}$ & $0.52 \pm 0.01^{\mathrm{cd}}$ & $66.70 \pm 1.83$ & $-0.18 \pm 0.28^{\mathrm{a}}$ & $15.36 \pm 0.90^{\mathrm{a}}$ & 5.95 \\
\hline Frozen blendered & $2.25 \pm 0.34^{\mathrm{a}}$ & $0.68 \pm 0.13^{\mathrm{ab}}$ & $0.60 \pm 0.04$ & $0.22 \pm 0.01^{\mathrm{a}}$ & $0.54 \pm 0.01^{\mathrm{cd}}$ & $66.73 \pm 3.04$ & $-0.31 \pm 0.12^{\mathrm{a}}$ & $15.08 \pm 0.45^{\mathrm{a}}$ & 5.72 \\
\hline Boiled blendered & $2.57 \pm 0.21^{\mathrm{ab}}$ & $0.71 \pm 0.08^{\mathrm{ab}}$ & $0.57 \pm 0.03$ & $0.27 \pm 0.02^{\mathrm{b}}$ & $0.55 \pm 0.01^{\mathrm{cd}}$ & $68.19 \pm 1.71$ & $-0.09 \pm 0.21^{\mathrm{a}}$ & $15.14 \pm 1.35^{\mathrm{a}}$ & 4.89 \\
\hline
\end{tabular}

Letters $\mathrm{a}, \mathrm{b}, \mathrm{c}$ indicate the significant differences between the mean values in columns $(\mathrm{p} \leq 0.05)$. $\mathrm{L}^{*}=(0$ (black) and $100($ white $)) ; \mathrm{a}^{*}=(-\mathrm{a}($ greenness $)$ and $+\mathrm{a}($ redness $)) ; \mathrm{b}^{*}=(-\mathrm{b}$ (blueness) and $+\mathrm{b}$ (yellowness)); $\Delta \mathrm{E}=$ difference of color. 


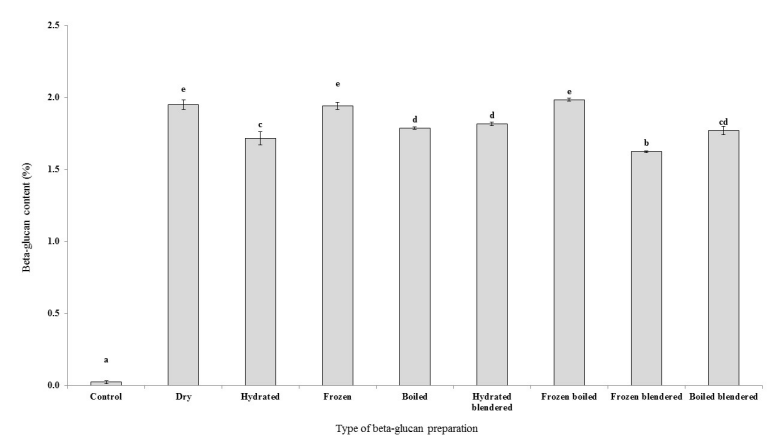

Figure 5. Content of $\beta$-glucan in bread crumb prepared with beta-glucan preparation after different pretreatment. Letters $a, b, c$ indicate the significant differences between the mean values in columns $(p \leq 0.05)$.

The different values of water activity could be explained by water crystal formation during freezing and sublimation (Carrillo-Meza et al., 2016).

\subsection{Beta-glucan content}

The content of beta-glucan is considered one of the most important parameters in the addition of fiber to bakery products. In our study, we researched the influence of pretreating beta-glucan preparations on the concentration of this compound. Bread content ranged from 1.62 to $1.99 \mathrm{~g}$ beta-glucan / $100 \mathrm{~g}$ of product (Figure 5). It seems that the best way of pretreatment in terms of beta-glucan preservation is drying, freezing or boiling after freezing the beta-glucan preparation (significant at $p \leq 0.05$ ). The mechanism of this phenomenon could consist of a higher particle size which stabilizes the longer polymeric chains of beta-glucan more so than the blendered samples. The least effective process is blendering after freezing. The beta-glucan presence in a control sample resulted from the addition of baker's yeast to the product which contains a small amount of this compound. We also correlated the concentration of beta-glucan with other parameters that we measured. It turns out that a higher level of beta-glucan in bread significantly influenced the color $\left(L^{*}:-0.711, a^{\star}: 0.742\right.$ and $\left.b^{*}: 0.757\right)$. Other parameters that were significantly influenced by beta-glucan addition but with lower Pearson coefficients were springiness (0.477) and cohesiveness (0.349) as well as mean pore size (0.410). Other research revealed that the beta-glucan addition stabilized the air cells in bread and therefore caused the coalescence of the bread's structure (Jalil et al., 2015).

\section{Conclusions}

Beta-glucan is a widely recognized health-beneficial food ingredient which could result in a good physiological response in the human organism. Our study reveals that there could be several pretreatments of beta-glucan preparations which could cause better technological properties of bread with beta-glucan addition. In general, the best performing method was boiling the beta-glucan preparation following dough addition. This had highest quality properties compared to others for most measured traits. Therefore, we recommend the industrial application of boiling the beta-glucan preparation prior to use in bread making as this method increases the fortified bread quality and has a higher content of beta-glucan in final product.

\section{References}

Aghamirzaei, M., Peighambardoust, S. H., Azadmard-Damirchi, S., \& Majzoobi, M. (2015). Effects of grape seed powder as a functional ingredient on flour physicochemical characteristics and dough rheological properties. Journal of Agricultural Science and Technology, 17, 365-373.

Altamirano-Fortoul, R., \& Rosell, C. M. (2011). Physico-chemical changes in breads from bake off technologies during storage. Lebensmittel-Wissenschaft + Technologie, 44(3), 631-636. http:// dx.doi.org/10.1016/j.lwt.2010.04.018.

Ames, N., Storsley, J., \& Tosh, S. (2015). Effects of processing on physicochemical properties and efficacy of $\beta$-glucan from oat and barley. Cereal Foods World, 60(1), 4-8. http://dx.doi.org/10.1094/ CFW-60-1-0004.

Association of Official Analytical Chemists - AOAC. (2010). Official methods of analysis of the Association of Official Analytical Chemists. Arlington: AOAC International.

Benito-Román, Ó., Alonso, E., Gairola, K., \& Cocero, M. J. (2013). Fixedbed extraction of $\beta$-glucan from cereals by means of pressurized hot water. The Journal of Supercritical Fluids, 82, 122-128. http:// dx.doi.org/10.1016/j.supflu.2013.07.003.

Carrillo-Meza, A., Altamirano-Fortoul, R., \& Bárcenas, M. E. (2016). Effect of the antimicrobial agents addition on the stability of partbaked bread during refrigerated storage and on the sensory quality of full-baked bread. Journal of Food Research, 5(6), 95-101. http:// dx.doi.org/10.5539/jfr.v5n6p95.

Collar, C., \& Angioloni, A. (2014). Nutritional and functional performance of high $\beta$-glucan barley flours in breadmaking: mixed breads versus wheat breads. European Food Research and Technology, 238(3), 459469. http://dx.doi.org/10.1007/s00217-013-2128-1.

Erbas, M., Sekerci, H., Arslan, S., \& Durak, A. N. (2012). Effect of sodium metabisulfite addition and baking temperature on maillard reaction in bread. Journal of Food Quality, 35(2), 144-151. http:// dx.doi.org/10.1111/j.1745-4557.2012.00439.x.

European Food Safety Authority - EFSA. (2011). Scientific Opinion on the substantiation of a health claim related to barley beta-glucans and lowering of blood cholesterol and reduced risk of (coronary) heart disease pursuant to Article 14 of Regulation (EC) No 1924/2006. EFSA Journal, 9(12), 2470-2484. http://dx.doi.org/10.2903/j.efsa.2011.2470.

Harasym, J., Suchecka, D., \& Gromadzka-Ostrowska, J. (2015). Effect of size reduction by freeze-milling on processing properties of beta-glucan oat bran. Journal of Cereal Science, 61, 119-125. http:// dx.doi.org/10.1016/j.jcs.2014.10.010.

Jalil, A. M. M., Edwards, C., Combet, E., Ibrahim, M., \& Garcia, A. L. (2015). Combined effects of added beta glucan and black tea in breads on starch functionality. International Journal of Food Sciences and Nutrition, 66(2), 159-165. http://dx.doi.org/10.3109/09637486 .2014.971225. PMid:25578762.

Kariluoto, S., Edelmann, M., Nyström, L., Sontag-Strohm, T., Salovaara, H., Kivelä, R., Herranen, M., Korhola, M., \& Piironen, V. (2014). In situ enrichment of folate by microorganisms in beta-glucan rich oat and barley matrices. International Journal of Food Microbiology, 176, 38-48. http://dx.doi.org/10.1016/j.ijfoodmicro.2014.01.018. PMid:24561828. 
Kurek, M. A., Wyrwisz, J., \& Wierzbicka, A. (2017). Optimization of beta-glucan and water content in fortified wheat bread using Response Surface Methodology according to staling kinetics. Lebensmittel-Wissenschaft + Technologie, 75, 352-357. http://dx.doi. org/10.1016/j.lwt.2016.09.008.

Kurek, M. A., Wyrwisz, J., Piwińska, M., \& Wierzbicka, A. (2015). Influence of the wheat flour extraction degree in the quality of bread made with high proportions of beta-glucan. Food Science and Technology, 35(2), 273-278. http://dx.doi.org/10.1590/1678-457X.6537.

Kurek, M., Wyrwisz, J., Piwińska, M., \& Wierzbicka, A. (2016). The effect of oat fibre powder particle size on the physical properties of wheat bread rolls. Food Technology and Biotechnology, 54(1), 4551. http://dx.doi.org/10.17113/ftb.54.01.16.4177. PMid:27904392.

Liu, R., Li, J., Wu, T., Li, Q., Meng, Y., \& Zhang, M. (2015). Effects of ultrafine grinding and cellulase hydrolysis treatment on physicochemical and rheological properties of oat (Avena nuda L.) $\beta$-glucans. Journal of Cereal Science, 65, 125-131. http://dx.doi. org/10.1016/j.jcs.2015.07.002.

López, E. P. (2014). Influence of the addition of lupine protein isolate on the protein and technological characteristics of dough and fresh bread with added Brea Gum. Food Science and Technology, 34(1), 195-203. http://dx.doi.org/10.1590/S0101-20612014005000016.

Martínez, M. M., Díaz, Á., \& Gómez, M. (2014). Effect of different microstructural features of soluble and insoluble fibres on glutenfree dough rheology and bread-making. Journal of Food Engineering, 142, 49-56. http://dx.doi.org/10.1016/j.jfoodeng.2014.06.020.

Mudgil, D., Barak, S., \& Khatkar, B. S. (2016). Optimization of textural properties of noodles with soluble fiber, dough mixing time and different water levels. Journal of Cereal Science, 69, 104-110. http:// dx.doi.org/10.1016/j.jcs.2016.02.015.
Niemi, P., Faulds, C. B., Sibakov, J., Holopainen, U., Poutanen, K., \& Buchert, J. (2012). Effect of a milling pre-treatment on the enzymatic hydrolysis of carbohydrates in brewer's spent grain. Bioresource Technology, 116, 155-160. http://dx.doi.org/10.1016/j. biortech.2012.04.043. PMid:22609670.

Robertson, A. R. (1990). Historical development of CIE recommended color difference equations. Color Research and Application, 15(3), 167-170. http://dx.doi.org/10.1002/col.5080150308.

Sibakov, J., Myllymäki, O., Holopainen, U., Kaukovirta-Norja, A., Hietaniemi, V., Pihlava, J. M., Poutanen, K., \& Lehtinen, P. (2011). Lipid removal enhances separation of oat grain cell wall material from starch and protein. Journal of Cereal Science, 54(1), 104-109. http://dx.doi.org/10.1016/j.jcs.2011.04.003.

Symons, L. J., \& Brennan, C. S. (2004). The effect of barley $\beta$-glucan fiber fractions on starch gelatinization and pasting characteristics. Journal of Food Science, 69(4), 257-261. http://dx.doi.org/10.1111/j.1365-2621.2004. tb06325.x.

Taghinia, P., Ataye Salehi, E., \& Sheikholesami, Z. (2016). Impact of pretreated rice bran on wheat dough performance and barbari bread quality. Journal of Agricultural Science and Technology, 18, 135-144.

Tosh, S. M., Brummer, Y., Miller, S. S., Regand, A., Defelice, C., Duss, R., Wolever, T. M. S., \& Wood, P. J. (2010). Processing affects the physicochemical properties of $\beta$-glucan in oat bran cereal. Journal of Agricultural and Food Chemistry, 58(13), 7723-7730. http://dx.doi. org/10.1021/jf904553u. PMid:20527967.

Wang, Y. J., Mäkelä, N., Maina, N. H., Lampi, A. M., \& Sontag-Strohm, T. (2016). Lipid oxidation induced oxidative degradation of cereal beta-glucan. Food Chemistry, 197(Pt B), 1324-1330. http://dx.doi. org/10.1016/j.foodchem.2015.11.018. PMid:26675874. 